\title{
Replacement Inhibitors for Tank Farm Cooling Coil Systems (U)
}

by,

T. C. Hsu

Westinghouse Savannah River Company

Savannah River Site

Aiken, South Carolina 29808

This paper was prepared in connection with work done under the above contract number with the U.S. Department of Energy. By acceptance of this paper, the publisher and/or recipient acknowledges the U. S. Government's right to retain a nonexclusive, royalty-free license in and to any copyright covering this paper, along with the right to reproduce and to authorize others to reproduce all or part of the copyrighted paper. 


\section{DISCLAIMER}

This report was prepared as an account of work sponsored by an agency of the United States Government. Neither the United States Government nor any agency thereof, nor any of their employees, makes any warranty, express or implied, or assumes any legal liability or responsibility for the accuracy, completeness, or usefulness of any information, apparatus, product, or process disclosed, or represents that its use would not infringe privately owned rights. Reference herein to any specific commercial product, process, or service by trade name, trademark, manufacturer, or otherwise does not necessarily constitute or imply its endorsement, recommendation, or favoring by the United States Government or any agency thereof. The views and opinions of authors expressed herein do not necessarily state or reflect those of the United States Government or any agency thereof.

This report has been reproduced directly from the best available copy.

Available to DOE and DOE contractors from the Office of Scientific and Technical Information, P.O. Box 62, Oak Ridge, TN 37831; prices available from (615) 576-8401.

Available to the public from the National Technical Information Service, U.S. Department of Commerce, 5285 Port Royal Road, Springfield, VA 22161. 


\section{DISCLAIMER}

Portions of this document may be illegible in electronic image products. Images are produced from the best available original document. 
WSRC-TR-95-0071

REVISION: 0

KEYWORDS:

Corrosion Inhibitor, Sodium Chromate,

Cooling Coil

Waste Tank

RETENTION: Permanent

CLASSIFICATION: U

Does Not Contain UCNI

Paul D. diaturem

REPLACEMENT INHIBITORS FOR TANK FARM COOLING COIL SYSTEMS(U)

Issued: March 10, 1995

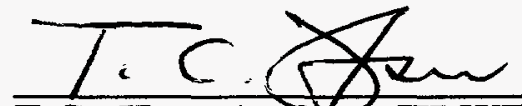

T.C. Hsu, Author, HLWE Tech Support

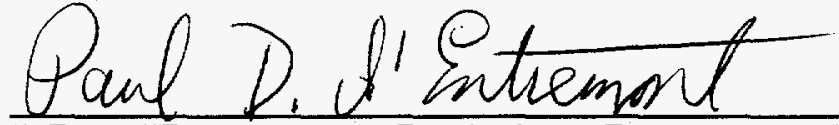

P.D. d'Entremont, Technical Reviewer, HLWE

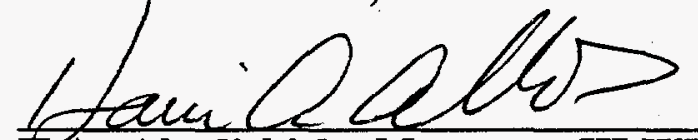

H.A. Abodishish, Manager, HLWE Tech Support

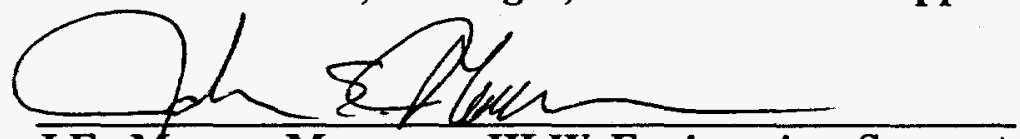

J.E. Marra, Manager, HLW Engineering Support

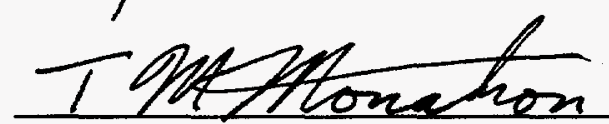

T.M. Monahon, Manager, HLW Engineering

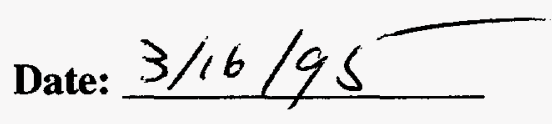

Date: $16 \operatorname{Mar} 45$

Date: $3 / 17 / 95$

Date: $3 / 20 / 95$

Date: $3 / 24 / 95$ 
WSRC-TR-95-0071

March 23, 1995

Page 2 of 9

\section{REPLACEMENT INHIBITORS FOR TANK FARM COOLING COIL SYSTEMS}

\section{Introduction:}

Sodium chromate has been an effective corrosion inhibitor for the cooling coil systems in Savannah River Site (SRS) waste tanks for over 40 years. Due to their age and operating history, cooling coils occasionally fail allowing chromate water to leak into the environment. When the leaks spill $10 \mathrm{lbs}$. or more of sodium chromate over a 24 -hr period, the leak incidents are classified as Unusual Occurrences (UO) per CERCLA (Comprehensive Environmental Response, Compensation and Liability Act). The cost of reporting and cleaning up chromate spills prompted High Level Waste Engineering (HLWE) to initiate a study to investigate alternative tank cooling water inhibitor systems and the associated cost of replacement.

\section{Summary And Recommendation:}

Several inhibitor systems were investigated as potential alternatives to sodium chromate. All would have a lesser regulatory impact, if a spill occurred. However, the conversion cost is estimated to be $\$ 8.5$ million over a period of 8 to 12 months to convert all 5 cooling systems. Although each of the alternative inhibitors examined is effective in preventing corrosion, there is no inhibitor identified that is as effective as chromate. Assuming 3 major leaks a year (the average over the past several years), the cost of maintaining the existing inhibitor was estimated at $\$ 0.5$ million per year. Since there is no economic or regulatory incentive to replace the sodium chromate with an alternate inhibitor, HLWE recommends that sodium chromate continue to be used as the inhibitor for the waste tank cooling systems.

\section{Discussion:}

\section{Evaluation Results}

To replace the sodium chromate in the HLWM waste tank cooling water systems with an alternate inhibitor system, the following cost comparison was obtained based on identifiable WAD (Work Authorization Document) records and experience-based cost estimations. However, the personnel costs of HLWM and other fixed costs could not be captured and therefore were not included.

\section{(1) Annual Maintenance Costs With Existing Sodium Chromate:\$ 504,300/yr}

Based on 1993 WAD Costs (3 leak incidents) [1,2,3,4]: \$354,300/yr Environmental Support (from many diverse groups)

(1 man-year@ @ \$150K ea):

$\$ 150,000 / \mathrm{yr}$

(2) Annual Maintenance Costs With Alternate Inhibitor:

(3) Removing Chromate \& Installing Alternate Inhibitor:
\$ Unknown

$\$ 8,500,000$

Itemized costs for (3) are listed in Table 1.

Based on the information available at this time, there is no incentive to replace the sodium chromate with an alternate inhibitor. No practical inhibitor has been identified that is as effective as chromate. Although chromate has some regulatory concerns and costs; the potential concerns, unknown maintenance cost of other inhibitors, and the cost of changing inhibitors make them less desirable. Changing to another inhibitor is not recommended unless (1) another inhibitor is identified that is more effective, (2) a less costly scheme is identified for changing inhibitors, or (3) some new mandate (such as new regulations) requires the change. 
WSRC-TR-95-0071

March 23, 1995

Page 3 of 9

Table 1. Removing Sodium Chromate by Flushing/Draining and Installing Alternate Inhibitor

Total Cost Estimate For All Five (5) Pumphouses*

Work Package Preparation:

$$
5 \mathrm{x} \$ 20 \mathrm{k}=\$ 100,000
$$

Operations Procedures Prep: $\quad(\$ 98 k+5 \times 10 \times \$ 20 k)=\$ 1,098,000$

(each pumphouse may require as many as 10 iterations to reduce chromate to the desired level)

Training:

For HLWO and/or vendor personnels: $\$ 98 k+5 \times \$ 20 k=\$ 198,000$

Excavation \& Tapping of Low Points:

Maintenance Procedures:

Tapping of Low Points:

Execution :

Disposal Of Waste Generated:

Transportation:

Temporary Storage:

Disposal:
$(\$ 65 \mathrm{k}$

$\begin{array}{lll}+5 \times \$ 15 k) & = & \$ 140,000 \\ \mathbf{5 x} \$ 15 k & = & \$ 75,000\end{array}$

$5 \mathrm{x} \$ 20 \mathrm{k}=\$ 100,000$

$\begin{array}{llr}\mathbf{5 x} \$ 25 \mathrm{k} & = & \$ 125,000 \\ \mathbf{5 x} \$ 100 \mathrm{k} & = & \$ 500,000 \\ \mathbf{5 x} \$ 500 \mathrm{k} & = & \$ 2,500,000\end{array}$

Lab Analyses:

20 sample/pumphouse; 3 tests/sample: $\quad 5 \times 20 \times 3 \times \$ 600=\quad \$ 180,000$

SRTC Basic R\&D Support:

(1) Alternate Inhibitor Characterization Tests

(2) Resin Tests

(3) Passivation Kinetics Study

(4) Phasing-in Strategy

(5) Incompatibility Determination

2 Man-year@ \$150k: 2x\$150k = \$300,000

Environmental Oversight \& Technical Support (From Diverse Groups):

Permitting, SIRIM Occurrence Reporting, Cleaning Up

2 Man-year@ @150k ea

$2 \times \$ 150 \mathrm{k}=\$ 300,000$

Total $=\$ 5,616,000$

Contingencies@50\%:

$1.5 \times \$ 5,616,000=\$ 8,424,000$

$\simeq \$ 8.500 .000$

* Uncaptured personnel costs and other fixed costs were not included in this table. Cost estimate for preparing work package, operations procedure, maintenance procedure and personnel training are based on reference [19] with adjustments. 
WSRC-TR-95-0071

March 23, 1995

Page 4 of 9

\section{Background:}

Sodium chromate has been an effective corrosion inhibitor for the cooling coil systems in SRS waste tanks for over 40 years $[5,6,7]$. In the recent past, sodium chromate's reportable quantity (RQ) as a hazardous substance under CERCLA (Comprehensive Environmental Response, Compensation and Liability Act) has been reduced from 1000 to $10 \mathrm{lbs}$. per 24 hours for SRS [8]. Thus, there is an increasing incentive to find an alternate inhibitor. When cooling water leaks from the coil system into the soil, the chromium content could cause the affected soil to be classified as hazardous waste under RCRA (Resource Conservation and Recovery Act), if the chromium concentration as measured by a TCLP (Toxicity Characteristic Leaching Procedures) test $[9,10]$ were to exceed 5 $\mathrm{ppm}$ [regulatory level (RL)] [11]. To date, no RCRA hazardous soil has ever been found around a chromate water leak at SRS waste tank farms. See Appendix A. The small number of UO (Unusual Occurrence) incidents from chromate leaks are so classified solely due to CERCLA regulation. However, the alternate inhibitor should be either non-hazardous or much less hazardous so the contaminated soil would not become hazardous waste or have a much greater RL than chromium under RCRA. Non hazardous or less hazardous substances usually either have higher or no RQ levels. There are several candidates considered or being investigated: inhibited water $(\mathrm{NaOH}+$ $\mathrm{NaNO}_{2}$ ) [12], sodium molybdate \& sodium hydroxide, and sodium molybdate \& sodium silicate $[13,14]$.

Regarding inhibitor effectiveness, the qualitative descending ranking generally accepted is chromate, nitrite, and molybdate. However, from a cost viewpoint of post-leak treatment of hazardous waste and the ensuing reports-filing per CERCLA and RCRA with the regulatory agencies, molybdate systems certainly are favored as molybdate is not listed as hazardous under either CERCLA or RCRA. Therefore molybdate systems are free of regulatory concerns. From the viewpoint of effectiveness, simplicity and familiarity to the operations personnel, inhibited water $(\mathrm{NaOH}+$ $\mathrm{NaNO}_{2}$ ) is a good choice, as it is the standard corrosion inhibitor for the waste tanks (with high caustic and nitrate waste) at SRS. Though $\mathrm{NaNO}_{2}$ is still a hazardous substance, its RQ (at $100 \mathrm{lbs}$ ) is 10 times that of chromate; soil contaminated with nitrite is not hazardous under RCRA. Therefore the chance of having a UO (Unusual Occurrence) incident is reduced. Inhibited water leaked or spilled into soil may still need post-leak treatment due to the requirements of CERCLA at lower reporting levels. However detailed investigation of inhibited water as a corrosion inhibitor for a carbon steel system recirculating cooling water has never been performed.

One of the purposes of this evaluation is to obtain a high-spot estimate of the scope and cost to replace sodium chromate with one of the candidates. This would establish whether, under the present circumstances of tight budget and manpower, the replacement of chromate is a task worth pursuing.

\section{Criteria Used To Evaluate Alternate Inhibitors:}

A total of 7 criteria were used to judge the effectiveness of the alternate inhibitor systems.

(1) Corrosion Inhibition Effectiveness: It must be confirmed to be an effective inhibitor.

(2) CERCLA: It must be non-hazardous or much less hazardous (w/orders of magnitude larger $\mathrm{RQ}$ ) than sodium chromate.

(3) RCRA: Its contaminated soil must be non-hazardous or much less hazardous (w/orders of magnitude larger RL) than that of chromium.

(4) Radiation: It must be stable and effective in high radiation field.

(5) Temperature: It must be stable and effective at high temperature.

(6) Compatibility: It must be compatible with current and future SRS waste streams.

(7) Cost: The replacement cost must be acceptable. 
WSRC-TR-95-0071

March 23, 1995

Page 5 of 9

\section{Past Investigations at SRTC}

From past investigations at SRTC, the two molybdate inhibitor systems have been identified as candidates for consideration with further testings on-going [13,14]. Nitrite as an inhibitor had been considered but was dropped due to its being a hazardous substance under CERCLA [12].

\section{Issues Considered in Evaluating New Inhibitors:}

A number of issues are associated with the potential replacement of the existing sodium chromate inhibitor system. The major issues are described below.

1. Chromate Removal and New Inhibitor Installation:

There are two key requirements that must be met during the inhibitor replacement.

(1) During the interim (from start of chromate removal to complete formation of the new protective inhibitor film), the coil internal surfaces must be fully protected. If the transition period is too long or if a certain line section is stagnant [13], the coil interior may be irreversibly exposed to potential pitting for not having the protective film formed.

(2) To prevent waste from being sucked into and pumped through the coils, the coils in waste tanks must maintain their positive pressure, with respect to the maximum hydrostatic head in the tanks, during the removal / installation phase.

Execution Modes For Removal / Installation Investigated.

(1) Selectively absorbed using suitable resin:

A potential resin candidate [DOWEX SBR (hydroxide form)] [15] that can selectively absorb chromate from the other ions present using exhaustive recirculation has been identified. It may require much recirculation time and many bed volumes of resin to reach the low chromium concentration level desired $(\leq 5 \mathrm{ppm})$. How long it would take is not yet known. As a second option, it would be adequate to reduce the chromium concentration to $9 \mathrm{ppm}$. This is equivalent to a sodium chromate concentration $<28 \mathrm{ppm}$, which means the total residual sodium chromate inventory in even the largest systems is less than the CERCLA RQ (10 lbs). This second option can eliminate UO incidents, but may still need post-leak treatment and low-level reporting. In addition, long-term storage of the chromium saturated resin after removal from the cooling coil systems needs to be considered and tested.

(2) Stepwise dilution by caustic water or the alternate inhibitor solution:

To reach the $\leq 28 \mathrm{ppm}$ sodium chromate level, simple dilution calculations estimate a minimum of 5 iterations of $1 / 2$-system volumes are needed for the high end of $750 \mathrm{ppm}$ chromate, or 4 iterations of $1 / 2$-system volumes for the low end of $450 \mathrm{ppm}$. One half of the system volume will be flushed/drained at a time, while the other half consists of coils in the tanks will be valved off to maintain the positive pressure. Then fresh caustic solution will be added to fill the emptied half and re-circulated throughout the whole system for complete mixing before the next flushing/draining iteration. Such iterations are repeated until the desired low chromate level is reached. The total volume for all five (5) cooling water systems in both tank farms is about 141,000 gallons. At five (5) $1 / 2$ system volumes of flushing water or solution, it generates about 353k gallons. At four (4) $1 / 2$ system-volumes, it would generate about $282 \mathrm{k}$ gallons in the replacing process. Since linearity in removal efficiency throughout the entire concentration range was assumed, 
WSRC-TR-95-0071

March 23, 1995

$\therefore \quad$ Page 6 of 9

these quoted waste volumes would be the low estimates. Therefore, the actual waste volume to be generated probably would be much higher.

After complete dilution, the alternate inhibitor is then added and re-circulated into all sections of a cooling coil system.

2. Alternate Inhibitors:

Before replacement can be considered, the effectiveness of the alternative inhibitor must be demonstrated.

(1) There has been no confirmatory lab study done on the use of inhibited water as corrosion inhibitor for open carbon steel pipe system, circulating cooling water for extended periods of time. [In SRTC's preliminary tests using inhibited water, pitting began to appear at around $70 \mathrm{deg} . C$. Also, in open systems, nitrite can become food for certain MIC (microbiologiacally influenced corrosion) bacteria which oxidize nitrite into nitrate and form slime along walls [16,17] causing corrosion.]

(2) The testing of the two molybdate systems has been completed at SRTC with completion of the analyses of data and the final report pending.

3. Full-scale Implementation:

Prior to initiating a program to replace the inhibitor, the following issues must be resolved.

(1) The optimal way (rates, concentrations, etc.) to phase in the new inhibitor system either simultaneously while removing the existing chromate or separately The inner surfaces of the cooling coils of a system must be fully protected during this transition period. This could be days or months. This is a transition or change-over period before the new inhibitor completes the formation of its own protective coat on the inner surfaces of the coils. For its resolution, pilot-scale testing of phasing-in strategy needs to be conducted.

(2) The other practical tasks (steps) and details involved in replacing the chromate with an alternate inhibitor that could have major impact on full-scale implementation of inhibitor removal / installation. These tasks need to be identified and tested as needed.

(3) The advisability of subcontracting this removal / installation task to a qualified vendor must be evaluated and decided.

(4) The method of disposing either the chromate-contaminated liquid inventory or the solid resin-bed volume generated must be evaluated and decided.

4. Other Considerations:

(1) Evaluation is needed of any incompatibility of the alternate inhibitor with current and future SRS waste streams.

(2) Evaluation is also needed for any incompatibilities between the inhibitor systems involved as well as between the inhibitors and the resin bed to be used.

(3) Also needed is the determination of the required concentration ranges of the alternate inhibitor to fully protect the coils for the wide temperature range that the coils would expect to experience during different processing modes, e.g., salt dissolution and sludge removal. 
5. Baseline Costs With Existing Sodium Chromate Inhibitor.

The primary issue associated with leaks in the existing cooling water system are the probability of having a UO, when a chromate leak occurs, and the cost of performing postleak repairs \& treatment and filing reports and other activities with the regulatory agencies.

The probability of being a UO when a chromate leak occurs is qualitatively estimated at around 5\% to $10 \%$ based on past history per W.G. Wabbersen, the SME (Subject Matter Expert engineer) on cooling system. The total number of manhours needed in addressing chromate leaks could not be captured. However, the baseline cost of about $\$ 0.5$ million per year in staying with the existing chromate was obtained using the 1993 WAD records in performing post-leak repairing \& treatment and report-filing as tabulated under Evaluation Results on page 2 of this report.

\section{Possible Vendor In Assisting Inhibitor Removal / Installation:}

Chem Nuclear Systems, Inc., Columbia, SC [(803) 758-1810] has experience in "dechromating" of the cooling water systems in the nuclear power industry. The operation was typically conducted during power plant's down period, using full draining and full refill. After reviewing the SRS well water specifications [18] adjusted with key cooling water parameters but without more details of operations configuration or requirements, Chem Nuclear Systems was not able to give a detailed estimate, considering the SRS chromate cooling water systems cannot be completely drained.

\section{REFERENCES}

[1] SRS-HTANK-93-20, "Tank 15 Chromate Leak," Off-Normal, 4/6/93; ORPS\# SR-WSRCHTANK-1993-0020); WAD \#212425, "Repair 6" Chromate Lines At Tank 15," \$104,300.

[2] SRS-HTANK-93-34, "Chromate Leak West of HDB-2," Off-Normal, 5/31/93; ORPS\# SRWSRC-HTANK-1993-0034; WAD \#212163, "Excavate, Repair, \& Backfill Chromate Cooling Water Line - HDB-2," $\$ 200,000$.

[3] SRS-HTANK-93-53, "East Pumphouse (241-14H) Waste Tanks and Cooling Water Supply Line," Non-routine, 8/30/93; ORPS\# N/A; WAD \#211742, "Repair Chromate Leak South of West Pumphouse," $\$ 50,000$.

[4] Abodishish, H.A. and M.E. Jamison, "Chromate Header Replacement Evaluation, SIRIM 930020-04 (U)," Memo to R.W. Wilson, and K.F. Lesko, 9/10/93.

[5] T.C. Hsu, Personal Communication with R.S. Ondrejcin, 9/19/94.

[6] T.C. Hsu, Personal Communication with Jack Watkins, 9/19/94.

[7] R.S. Ondrejcin, "Investigation Of Cooling Coil Corrosion In Radioactive-Waste Storage Tanks," DP-1425, Jan 1977, p. 10.

[8] 40 CFR 302.

[9] Toxicity Characteristic Leaching Procedure, test Method 1311 in "Test Methods for Evaluating Solid Waste, Physical/Chemical Methods," EPA Publication SW-846.

[10] South Carolina Hazardous Waste Management Regulations, R.61-79.261, Appendix II Method 1311 Toxicity Characteristic Leaching Procedure (TCLP). 
WंVSRC-TR-95-0071

March 23, 1995

Page 8 of 9

\section{REFERENCES (continued)}

[11] 40 CFR 261.24.

[12] D.T. Hobbs, "Effectiveness of Molybdate As A Corrosion Inhibitor In The Waste Tank Cooling Systems," DPST-88-687, July 11, 1988.

[13] B.J. Wiersma, "Recommendation for Alternate Cooling Water Inhibitor (U)," SRT-MTS-933086, July 28, 1993.

[14] B.J. Wiersma, "Action Plan: Confirmatory Testing Of Alternate Inhibitors For Waste Tank Cooling Water (U)," SRT-MTS-94-2009, April 14, 1994.

[15] T.C. Hsu, Personal consultation with Dr. Harold Fravel, Jr., Téchnical Director (\&Resin Expert), Dow Chemicals, Palm Beach, FL @ (407) 697-2444, 9/15/94.

[16] Betz Handbook of Industrial Water Conditioning, 8th Ed., Chap 24, p.173.

[17] Metal Handbook, 9th Ed, Vol 13, 1987, p.494.

[18] Well Water Analyses - SRS (H-Tank Farm), 1980, 1981, 1985. Obtained from Loren Stayer, Power Dept.

[19] H.A. Abodishish, "Startup OPC Funding Estimate for HDB-7 Container Building, Project S-2821 Pump Pit Diversion Box," 6/1/94. 
WSRC-TR-95-0071

March 23, 1995

Page 9 of 9

CC: G.T. Wright, 703-H

C.A. Polson, 707-H

G. Davis, 241-100F

W.D. Lanham, III, 707-H

W.A. Morrison, 241-100F

T.M. Monahon, 703-H

V.G. Dickert, 703-H

R.L. Salizzoni, 707-H

J.E. Marra, 703-H

H.A. Abodishish, 703-H

M.A. Ceravolo, 707-H

R.J. Rea/P.W. Norris, 707-H

W.C. Clark, 241-119H

E.D. Lee, $241-152 \mathrm{H}$

T. Ortner, 241-152H

W.E. Philllips, 241-152H

B.R. Hess, 241-102F

E. Saldivar, 703-H

W.F. Bates, 703-H

R.A. Scaggs, 703-H

P.D. d'Entremont, 703-H

G.K. Georgeton, 703-H

L.S. Livingston, 703-H

J.A. Pike, 703-H

S.D. Fink, 773-A

W.G. Wabbersen, 703-H

J.E. Burgin, 241-102F

N.C. Iyer, 773-A

B.J. Wiersma, 773-A

D.T. Hobbs, 773-A

C.B. Stevens, $742-6 \mathrm{G}$

C.L. Todaro, 742-6G

P. Suggs, 703-H

M.P. Dholakia, 703-H

ScientificTechnical Information, 703-43A [4 copies + diskette copy]

HLW FILE, 703-H

File Codes 175.3.2, 1010.0 
